\title{
Species Interactions Improve Above-Ground Biomass and Land Use Efficiency in Intercropped Wheat and Chickpea under Low Soil Inputs
}

\author{
Mourad Latati ${ }^{1}, * \mathbb{C}$, Peter Dokukin ${ }^{2}$, Adel Aouiche ${ }^{3}$, Nazih Yacer Rebouh ${ }^{2}$, Riad Takouachet ${ }^{1}$, \\ Elalia Hafnaoui ${ }^{1}$, Fatima Zohra Hamdani ${ }^{1}$, Fadila Bacha ${ }^{4}$ and Sidi Mohamed Ounane ${ }^{1}$ \\ 1 Laboratoire d'Amélioration Intégrative des Productions Végétales (C2711100), Département de Productions \\ Végétales, Ecole Nationale Supérieure Agronomique (ENSA), Avenue Hassane Badi, El Harrach, \\ Algiers 16200, Algeria; bouhenacheabderrahim@gmail.com (R.T.); souadeduc@gmail.com (E.H.); \\ hamdanifatmazohra@gmail.com (F.Z.H.); ounane2@yahoo.fr (S.M.O.) \\ 2 Peoples' Friendship University of Russia (RUDN University), 6 Miklukho-Maklaya St, Moscow 117198, \\ Russia; petrdokukin@mail.ru (P.D.); n.rebouh@outlook.fr (N.Y.R.) \\ 3 Ecole Supérieure des Sciences des Aliments et d'Industrie Agroalimentaire d'Alger (ESSAIA), Avenue \\ Ahmed Hamidouche, Route de Beaulieu, El Harrach, Algiers 16200, Algeria; aouicheadel@hotmail.com \\ 4 Institut National de la Recherche Agronomique d'Algérie (INRAA), Division Science du sol, \\ Beraki 16200, Algeria; m.latati@ensa.dz \\ * Correspondence: m.latati@yahoo.com; Tel.: +213-560939454; Fax: +213-21822729
}

Received: 22 September 2019; Accepted: 12 November 2019; Published: 16 November 2019

\begin{abstract}
Little is known about how the performance of legumes symbiosis affects biomass and nutrient accumulation by intercropped cereals under the field condition. To assess the agricultural services of an intercropping system; durum wheat (Triticum turgidum durum L.cv. VITRON) and chickpea (Cicer arietinum L.cv. FLIP 90/13 C) were cultivated as both intercrops and sole cropping during two growing seasons under the field trial, to compare plant biomass, nodulation, $\mathrm{N}$ and phosphorus (P) uptake, and $\mathrm{N}$ nutrition index. Both the above-ground biomass and grain yield and consequently, the amount of $\mathrm{N}$ taken up by intercropped durum wheat increased significantly ( $44 \%, 48 \%$, and $30 \%$, respectively) compared with sole cropping during the two seasons. However, intercropping decreased P uptake by both durum wheat and chickpea. The efficiency in use of rhizobial symbiosis (EURS) for intercropped chickpea was significantly higher than for chickpea grown as sole cropping. The intercropped chickpea considerably increased N $(49 \%)$ and P $(75 \%)$ availability in durum wheat rhizosphere. In the case of chickpea shoot, the $\mathrm{N}$ nutrition (defined by the ratio between actual and critical $\mathrm{N}$ uptake by crop) and acquisition were higher in intercropping during only the first year of cropping. Moreover, biomass, grin yield, and resource (N and $\mathrm{P})$ use efficiency were significantly improved, as indicated by higher land equivalent ratio (LER > 1) in intercropping over sole cropping treatments. Our findings suggest that change in the intercropped chickpea rhizosphere-induced parameters facilitated $\mathrm{P}$ and $\mathrm{N}$ uptake, above-ground biomass, grain yield, and land use efficiency for wheat crop.
\end{abstract}

Keywords: legume; cereal; symbiosis; aboveground; rhizosphere

\section{Introduction}

The main factors limiting crop productivity in agro-ecosystems are water, nitrogen $(\mathrm{N})$, and phosphorus (P) deficiency [1-3]. With the increase in global demand for agricultural and food products, the development of new sustainable agricultural strategies to exploit soil resources effectively (especially 
$\mathrm{P}$ and $\mathrm{N}$ ) has become an interesting priority. These new agricultural practices include intercropping legumes and cereals to ensure effective use of agricultural and environmental resources $[4,5]$.

Several studies have already shown that cereals-legumes intercrops increase yields and improve the efficiency in use of environmental resources by stimulating plant growth and yield compared with their respective sole cropping system. This is due to interspecific interaction of both complementarity and facilitation for nutrient use by intercropped species [6,7].

The improvement of $\mathrm{N}$ acquisition in cereal-legume intercropping and rotation systems has been widely reported in previous investigations, although performed at the laboratory scale in most cases studies. However, recent research studies were performed under field conditions $[8,9]$ and reported that intercropping legumes and cereals provide many ecological advantages and contribute to a suitable agriculture. These agricultural systems improve biomass, yield, and nutrient resources use efficiency through symbiosis for both intercropped legumes and cereals [10,11].

Most previous studies on cereal-legume intercropping assume implicitly that $\mathrm{P}$ and $\mathrm{N}$ acquisition by the cereal improves because the legumes are able to mobilize large amounts of $\mathrm{P}$ and $\mathrm{N}$ compounds $[9,12]$. Mechanisms that help to alter the rhizosphere processes of both intercropped species have been described [13], including mechanisms affecting soil nutrients availability. Indeed, cereal-legume intercropping can stimulate rhizosphere acidification through proton release by roots of $\mathrm{N}_{2}$-fixing legumes $[8,12]$. In contrast, alkalization can also enhance rhizosphere $\mathrm{P}$ availability in noncalcareous soils $[9,14]$. Soil respiration via carbon dioxide $\left(\mathrm{CO}_{2}\right)$ emissions was recently considered as a limiting factor that controls microorganisms and root-nodule symbiosis activities, which were responsible for altering $\mathrm{N}$ and $\mathrm{P}$ availability in the soil [12].

Intercropping practices are a valuable way of ecological intensification in order to ensure food security in Algeria. Indeed, the development of local farming practices has become a strategic necessity to sustain agro-ecosystem productivity at economic, social, and environmental levels. However, most northern Algerian soils are alkaline, in which $\mathrm{pH}$ varying from 7.5 to 8.5 [15] is considered to be a limiting factor for the growth and nodulation of legumes [16]. Fallow is one of the common farming systems that are actually practiced in Algerian agriculture. The first type of fallow is practiced to reduce weeds plants, conserve water, and enrich soil resources availability. However, under conventional field conditions, the second fallow is based on soil plowing without inputs addition (i.e., fertilizer and irrigation treatment).

The second practice is the most applied for ecological intensification in Algerian agricultural practices. In both cases, this practice is not profitable and does not allow either to satisfy the needs of the Algerian population or to better restore soil fertility [15,17]. Finding solutions for the Algerian soil problems to replace fallow systems by more profitable agricultural practices is, therefore, currently a major concern.

This research study is addressed in conventional agriculture practices, we studied the influence of cropping system on the performance of legumes and cereals in a field experiment. Consequently, this two-year field study aimed to highlight whether the intercropping chickpea (Cicer arietinum L.)-durum wheat (Triticum turgidum durum L.) might alleviate the negative effect of either P or N deficiency in northern Algerian soils. We hypothesize that the presence of chickpea intercrop with durum wheat will enhance $\mathrm{N}$ nutrition of the intercropped cereal and the biological $\mathrm{N}_{2}$ fixation for the legume via both interspecific interaction and facilitation processes.

This research study is addressed in conventional agriculture practices by considering both the farmers' profitability and the reduction of environmental dis-services. This study had three sub-objectives. First, to assess whether mixed crop (intercropping) of cereals-legumes rather than sole crop agriculture might be an advantageous agricultural practice in terms of yield and nutrient (e.g., $\mathrm{N}$ and $\mathrm{P}$ ) use efficiency. Secondly, the increase in $\mathrm{N}$ and $\mathrm{P}$ acquisition by intercropped durum wheat increase compared with sole cropping was studied. Indeed, the hypothesis that the increase of $\mathrm{P}$ acquisition results from $\mathrm{N}$ nutrition improvement will be also tested. Thirdly, it tested the relationship 
between the EURS (efficiency in use of rhizobial symbiosis) and the main process altering $\mathrm{N}$ and $\mathrm{P}$ availability in the rhizosphere of intercropped species.

\section{Materials and Methods}

\subsection{Experimental Site}

The study was carried out during 2014 to 2016 growing seasons under field conditions The experimental site is situated in the El Harrach region, northeast of Algiers $\left(36^{\circ} 43^{\prime} \mathrm{N}, 2^{\circ} 53^{\prime} \mathrm{E}\right.$, Frost-free days, elevation).The ombrothermic chart relative to El Harrach region (Supplementary Figure S1) revealed that the highest precipitations were noted in December for the two growing seasons (134 and $124 \mathrm{~mm}$ for 2014 and 2015, respectively), while April was the driest month over 2015 and 2016 seasons, with 0.0 and $5.0 \mathrm{~mm}$, respectively. During the two-year experiment, the coldest period was from December to February, with minimum temperatures recorded of 4.6 and $3.9^{\circ} \mathrm{C}$ respectively on February in 2015 and 2016 growing seasons (Figure S1). Physical and chemical soil properties of the experimental site showed that loam proportion $(46 \%)$ was higher compared with both clay $(28 \%)$ and sand $(26 \%)$ proportions. In terms of soil chemical properties, the top soil was alkaline ( $\mathrm{pH} 8.5)$, with $16 \mathrm{~g} \mathrm{~kg}^{-1}$ $\mathrm{CaCO}_{3}$ and a low content of organic matter (2.7\%). The agricultural conditions at this experimental site corresponded to $\mathrm{N}$ deficiency (Total $\mathrm{N}: 1.1 \mathrm{~g} \mathrm{~kg}^{-1}$ and inorganic-N $\left(\mathrm{N}^{-\mathrm{NH}_{4}}{ }^{+}+\mathrm{NO}_{3}{ }^{-}\right): 10 \mathrm{mg} \mathrm{N} \mathrm{kg}^{-1}$ ) and P sufficiency (Total P: $287 \mathrm{mg} \mathrm{kg}^{-1}$ and Olsen P: $25.5 \mathrm{mg} \mathrm{P} \mathrm{kg}^{-1}$ ).

\subsection{Cropping and Field Plot Design}

The experiment was carried out with one chickpea cultivar (Cicer arietinum L. cv. FLIP 90/13 C) and one durum wheat cultivar (Triticum turgidum durum L. cv. VITRON), commonly grown by Algerian farmers (Figure S2). The experimental design (Randomized Complete Block Design) was a plot divided into four blocks (four replicates), each block being further divided into four plots. Each plot was used for one of the following four cropping systems: chickpea, durum wheat, durum wheat intercropped with chickpea, and fallow. During the first and second growing seasons, the experiment covered an area of $270 \mathrm{~m}^{2}$, each plot being $5 \mathrm{~m} \times 3 \mathrm{~m}$. The plant density was based on standard farming practices: $30 \pm 3$ plants per $\mathrm{m}^{-2}$ for chickpea as sole crop, $300 \pm 15$ plants per $\mathrm{m}^{-2}$ for durum wheat as sole crop, and $30 \pm 3$ for chickpea and $200 \pm 10$ plants per $\mathrm{m}^{-2}$ for durum wheat as intercrops. In both sole crop and intercrops system, the distance between rows and plants for chickpea crop was 25 and $20 \mathrm{~cm}$, respectively. The two species were sown in the same row to maximize root proximity and chickpea-wheat rhizosphere interactions. The soils from the fallow were taken as a control, as well as from the rhizosphere of each species in crop system. While the same type of fallow treatments was practiced in the experiment field according to farmers' practices without fertilizers application. For crop management, intercropping is carried out under rain-fed conditions and without additional irrigation, except at the full flowering stage $(60 \mathrm{~mm}$ of irrigation was reported to mitigate the effects of water stress and ensure a normal crop development). For weed management, weeding is done manually by hand during two times from the cropping period to assess weed nuisance and minimize the adverse effects of chemical inputs.

\subsection{Plant and Soil Sampling and Measurements}

All sampling periods are shown in Figure S1. The first set of both plant ( 25 plants for each crop) and soil samples was taken at the full flowering stage for chickpea (120 days after sowing). Shoots were separated from the roots at the cotyledonary node, dried for $48 \mathrm{~h}$ at $65^{\circ} \mathrm{C}$, and then weighed. The nodules were separated from the roots, dried, and weighed separately. Samples of the soil from fallow sub-plots were taken as a control and were compared to the soil which was taken from both chickpea and durum wheat rhizosphere. Samples of the soil rhizosphere were also carefully detached from roots of both species. According to Hinsinger et al. [8], the rhizospheric soil was considered as the fraction of soil at wet sieving adhering to roots $(1-4 \mathrm{~mm})$ that was gently brushed, collected, and 
stored refrigerated at $4{ }^{\circ} \mathrm{C}$ for no more than three days prior to analysis. The rhizosphere soil of all plants sampled for each species was bulked for each replicate for each cropping system.

For the second set of samples, the crop yield for both chickpea and durum wheat was determined by harvesting all the plants within $1 \mathrm{~m}^{2}$ quadrants with four pseudo-replicates in each sub-plot, excluding the outer rows. The $\mathrm{N}$ concentration in the soil was determined using the Kjeldahl method [18], and the total $\mathrm{P}$ concentration in the plants (shoots, roots, and grains) and soil was determined using the malachite green method after digestion by nitric and perchloric acid. Note that we also performed these measurements with one hundred seeds, in order to calculate P and P uptake at the full flowering stage in a standard way; that is, by subtracting the seed content from the plant content $[9,19]$. The soil $\mathrm{P}$ availability was obtained by $\mathrm{NaHCO}_{3}$ extraction (Olsen method), and the rhizosphere $\mathrm{pH}$ was measured in soil suspended in purified water (soil:water ratio of 1:2.5; [20]). Soil N availability $\left(\mathrm{N}^{-N}{ }_{3}{ }^{-}+\mathrm{N}^{-\mathrm{NH}_{4}}{ }^{+}\right)$was determined using Henriksen's method (1980), and the soil calcium carbonate $\left(\mathrm{CaCO}_{3}\right)$ concentration was obtained in the laboratory by measuring the $\mathrm{CO}_{2}$ volume, as described by Horton and Newson [21]. N and P availability was measured in either bulk or rhizosphere soil during sowing and full flowering stages.

\subsection{Calculation}

The land equivalent ratio $(L E R)$ is considered to be one of the most important parameters for evaluating crop efficiency in the use of environmental resources in intercropping and sole cropping systems. The LER was determined for biomass, yield, and N-P uptake [10]. The LER was calculated as follows (Equation (1)):

$$
L E R_{\mathrm{ab}}=Y_{\mathrm{ab}} / Y_{\mathrm{aa}}+Y_{\mathrm{ba}} / Y_{\mathrm{bb}}
$$

where $Y_{a a}$ and is the parameter for species " $a$ " as a sole crop; $Y_{b b}$ is the parameter for species " $\mathrm{b}$ " as a sole crop; $Y_{\mathrm{ab}}$ is the parameter for species "a" intercropped with species " $\mathrm{b}$ ", and $Y_{\mathrm{ba}}$ is the parameter for species " $\mathrm{b}$ " intercropped with species "a". If $L E R_{\mathrm{ab}}$ is greater than 1 , there is an advantage to using intercropping [10,22].

In this study, LER was used as an indicator for land use efficiency in intercropping over sole cropping system, this performance assessment via LER estimating was analyzed according to grain yield, total aboveground, and $\mathrm{N}$ and $\mathrm{P}$ uptake parameters. However, the performance in $\mathrm{N}$ use efficiency in intercropping (LER estimation) was tested and confirmed according to another diagnostic tool (nitrogen nutrition index: NNI), which was used to analyze the actual plant $\mathrm{N}$ status in crops to better explain aboveground and yield variation from differences in crop $\mathrm{N}$ status. Thus, the $\mathrm{N}$ status for each cropping system (intercrop and sole crop) for both durum wheat and chickpea was determined using the NNI index [1,23].

The NNI is defined by the ratio (Equation (2)) between the actual crop $\mathrm{N}$ uptake ( $\mathrm{Na}$ ) and the critical $\mathrm{N}$ uptake $(\mathrm{Nc})$, corresponding to the actual crop biomass Wa. Nc was defined as the minimum $\mathrm{N}$ uptake for the maximum crop biomass (Equation (3)).

$$
\begin{gathered}
N N I=N a / N c \\
N c=a_{c} W^{-b}
\end{gathered}
$$

where $\mathrm{a}_{\mathrm{c}}$ is the critical plant $\mathrm{N}$ concentration for $W=1 \mathrm{t} \mathrm{ha} \mathrm{a}^{-1}, \mathrm{~b}$ is a little bit more variable among species. The $a_{c}$ and $b$ coefficients were determined ( 3.4 and 0.37 for durum wheat and 5.1 and 0.32 for chickpea, respectively) by Plènet and Lemaire [24].

\subsection{Statistical Analysis}

The data were tested for homogeneity of variance before statistical analyses. The effects of the cropping system (intercropping and sole crop) and growing season (2015 and 2016) on plant biomass, $\mathrm{N}$ and $\mathrm{P}$ uptake, and $\mathrm{N}$ and $\mathrm{P}$ availability in the rhizosphere and grain yield were determined using 
analysis of variance (ANOVA) at a significance of $p$-value $=0.05$, and Tukey's test was used to determine whether the difference between mean values for each treatment was significant. The relationships between shoot and nodule dry weights (EURS) were determined by parametric regression [25]. The statistical analyses were performed using Statistica 8 for Windows.

\section{Results}

\subsection{Plant Growth and Nodulation}

Cropping system and growing season significantly influenced shoot and root growth of durum wheat and chickpea (Figure 1). For chickpea, the dry weight was lower for the intercrops than for the sole crops for both the shoots ( $40 \%$ in 2015 and 55\% in 2016) and the roots (54\% in 2015 and $46 \%$ in 2016) dry weight (Figure 1A,B). However, for durum wheat, the root dry weight was significantly higher $(29 \%)$ with intercropping in the first growing season (Figure 1B), whereas there was a significant difference in shoot dry weight only in the second year (2016), with an increase of $25 \%$ (Figure 1A). The total dry weight of the shoots of chickpea and durum wheat was significantly higher for the intercrops than for the sole crops (44\% in 2015 and 49\% in 2016, Figure 2A). The Figure 2B shows that the nodulation significantly depended on the cropping systems in both 2015 and 2016 seasons. The nodule biomass was significantly lower for intercropping than for sole cropping during both 2015 and 2016 growing seasons (Figure 2B).
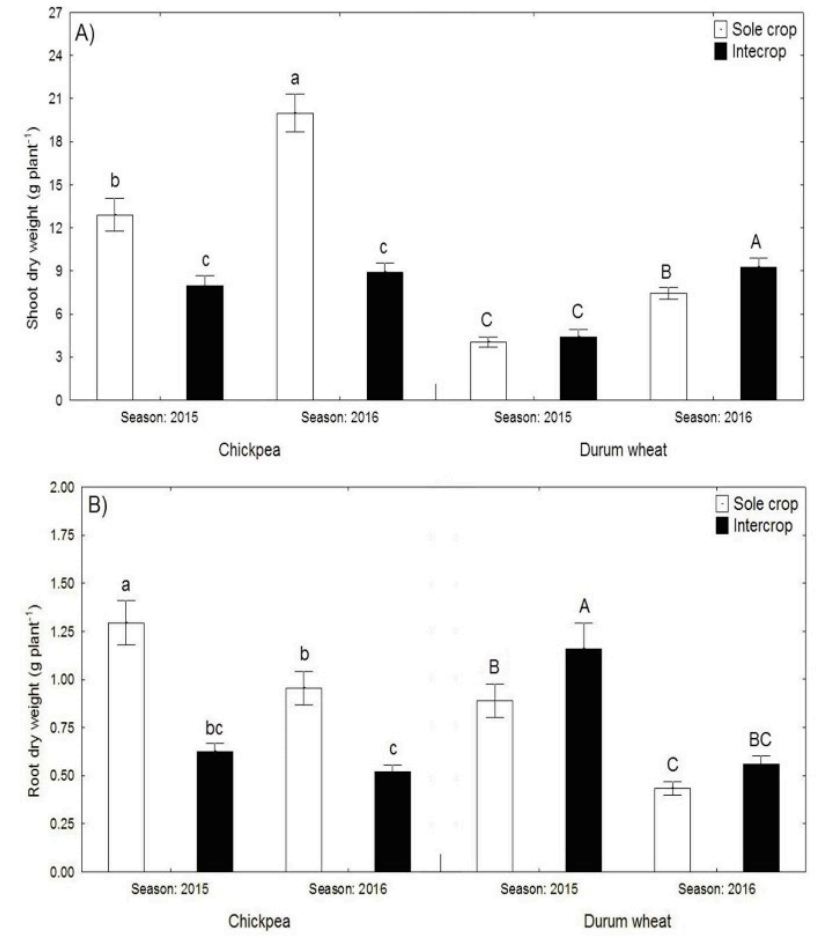

Figure 1. Shoot (A) and root (B) dry weight of chickpea and durum wheat as sole crops and intercrops in 2015 and 2016. Data are means and standard error (SE) of 25 plants harvested at 120 days after sowing. Bars with the different letters compare cropping systems and years within a crop and are significantly different at $p<0.05$.

\subsection{Total Biomass, Grain Yield, and Land Equivalent Ratio (LER)}

The grain yield of mixed crop (chickpea and durum wheat) was significantly higher for the intercrops than for the sole crops (48\% in 2015 and 40\% in 2016, Figure 3A). The LER was significantly higher than 1 for total dry weight, which was assessed at full flowering stage: LER TDW $_{\text {(1.8 in }} 2015$ and 1.43 in 2016) and grain yield (1.03 in 2015 and 1.41 in 2016, Figure 2B). For the second growing season, 
the LER for TDW was lower (20\%) than for the first growing season, but, for grain yield, the LER was higher $(36 \%)$ than for the first growing season.
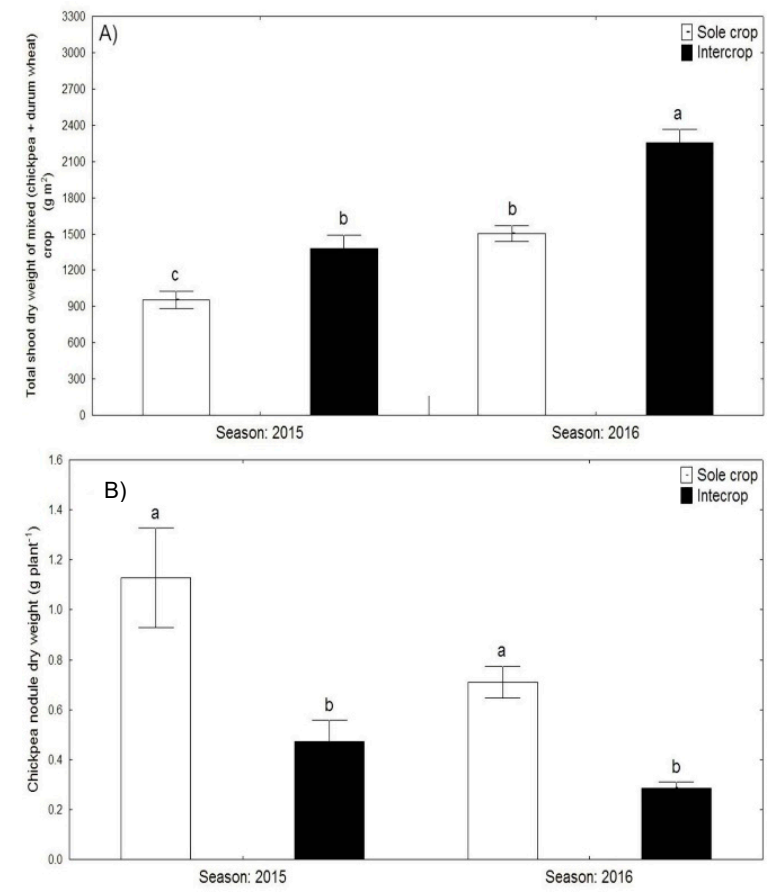

Figure 2. Total shoot dry weight (chickpea + wheat) per land area (A) and nodule biomass (B) as intercrops or sole crops in 2015 and 2016. Data are means and SE of 25 plants harvested at 120 days after sowing. Bars with the different letters compare cropping systems and years within a crop and are significantly different at $p<0.05$.
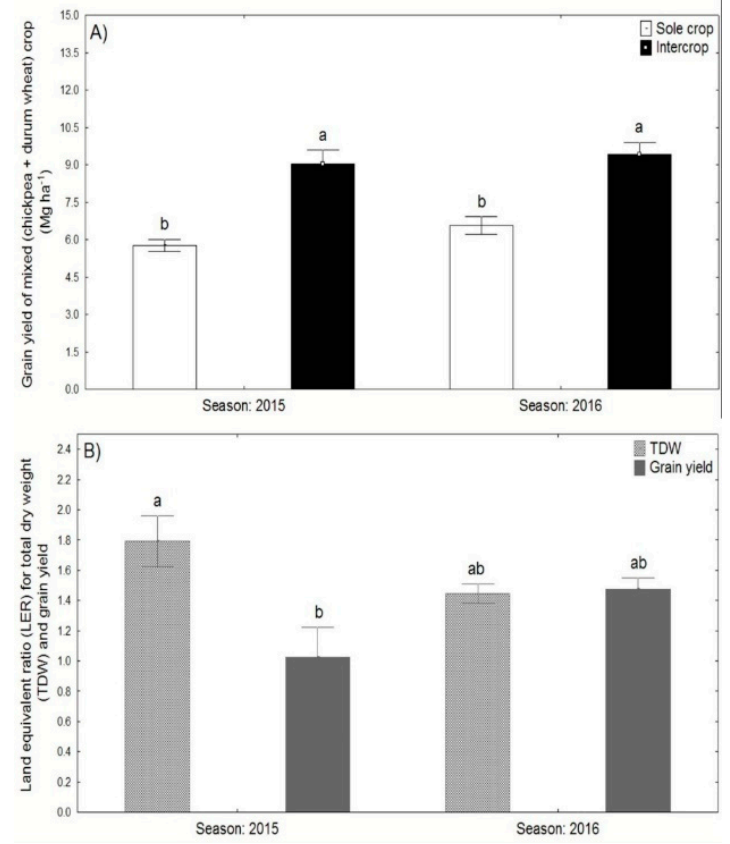

Figure 3. Grain yield of mixed crop (chickpea + durum wheat) per land area (A) and land equivalent ratio (LER) for total dry weight (TDW) and grain yield in 2015 and 2016 (B). Data are means and SE of four replicates. Bars with the different letters compare cropping systems and years within a crop and are significantly different at $p<0.05$. 


\subsection{Symbiosis Performance for Plant Growth}

The EURS, calculated as the slope of the linear regression between plant and nodule biomass $[25,26]$ was considerably different for chickpea grown in both intercrops and sole crop system. For each chickpea plant, the shoot dry weight (SDW) was plotted against the nodule dry weight (NDW) (Figure 4). In 2015, the EURS for intercropped chickpea (11.7 g DW shoot $\mathrm{g}^{-1} \mathrm{DW}$ nodule, $\mathrm{R}^{2}=0.81$, $p=0.001)$ was 2.5 times higher than for chickpea as a sole crop ( $4.7 \mathrm{~g}$ DW shoot $\mathrm{g}^{-1} \mathrm{DW}$ nodule, $\mathrm{R}^{2}=0.41, p=0.001$, Figure 4A,B). However, in 2016, the EURS was $24 \%$ higher for chickpea as a sole crop (16.2 g DW shoot $\mathrm{g}-1 \mathrm{DW}$ nodule, $\left.\mathrm{R}^{2}=0.60, p=0.001\right)$ than for intercropped chickpea (13 g DW shoot $\mathrm{g}-1 \mathrm{DW}$ nodule, $\mathrm{R}^{2}=0.37, p=0.01$ ).

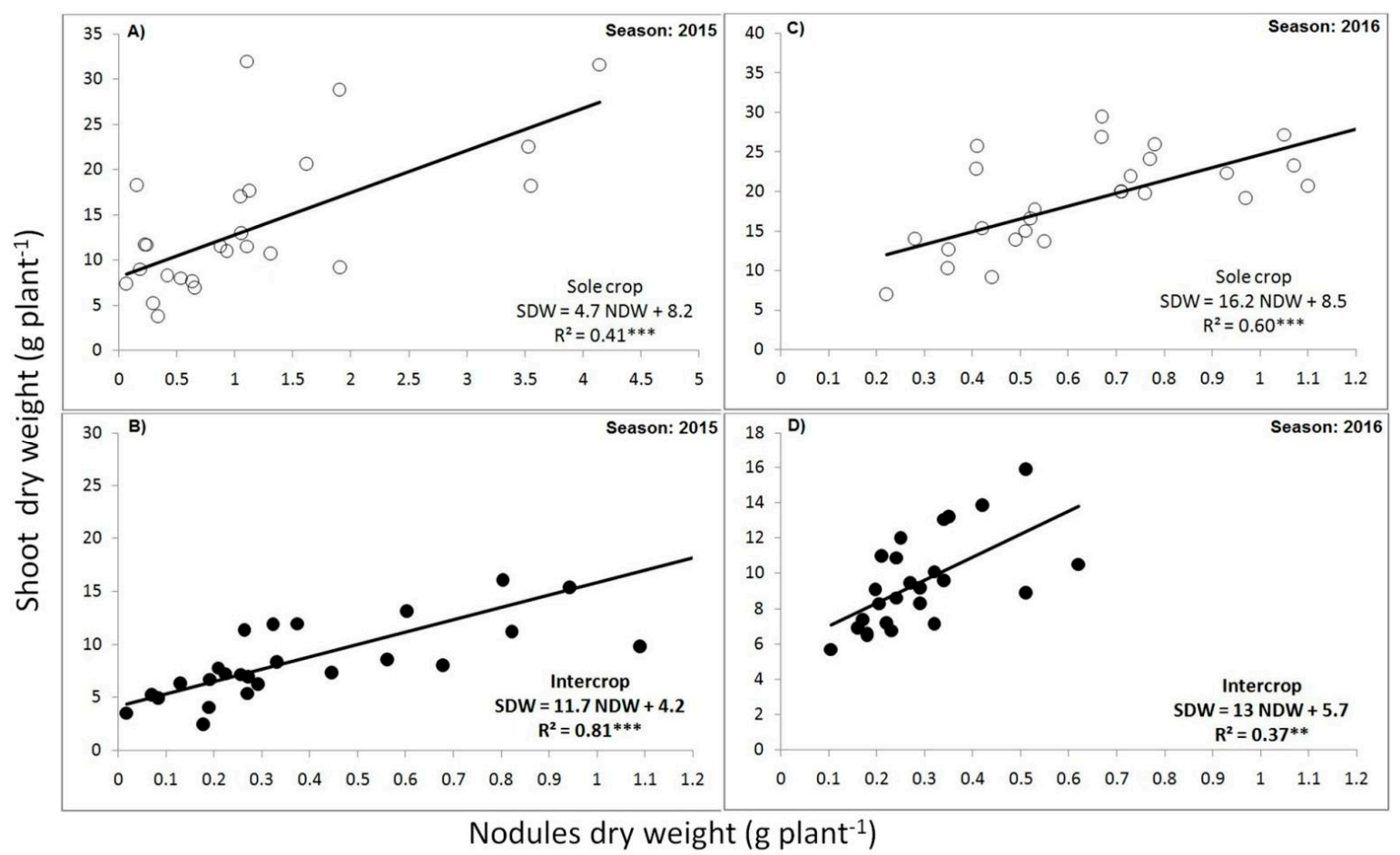

Figure 4. Efficiency in the use of rhizobial symbiosis (EURS) of chickpea as sole crop (A and C: opened circle) and intercrops (B and D: filled circle) in 2015 and 2016. The equations inserted in the graphs are the linear regression functions. The slope of each equation represents the estimated value of EURS. All regressions were calculated for 25 plants harvested 120 days after sowing. Asterisks "** and ***" denote significance at $p<0.01$ and $p<0.001$, respectively.

\subsection{Plant $N$ and P Uptake by Species}

The $\mathrm{N}$ concentration in shoots and roots and $\mathrm{N}$ uptake by durum wheat and chickpea are given in Table 1, and P concentrations are given in Table 2. For both chickpea and durum wheat, the cropping system had a significant effect on the $\mathrm{N}$ concentration and $\mathrm{N}$ uptake, except for the $\mathrm{N}$ concentration in the roots of durum wheat. For intercropped chickpea, shoot $\mathrm{N}$ concentration was significantly higher compared with sole crop (58\% in 2015 and 19\% in 2016). However, $\mathrm{N}$ root concentration in intercrop was only greater $(46 \%)$ in 2015 , while it was significantly lower (15\%) in 2016 season (Table 1). However, for chickpea grown as a sole crop, the total $\mathrm{N}$ uptake was significantly lower than for intercropped chickpea only in 2015 growing season. The difference was not significant in 2016, with the N root concentration being more than double that of intercropped chickpea (Table 1). For durum wheat, the $\mathrm{N}$ concentration in the shoots $(59 \%-65 \%)$ and total $\mathrm{N}$ uptake $(30 \%-19 \%)$ was significantly higher for intercropping than for sole crops for both years. 
Table 1. Nitrogen concentration in shoots and roots and $\mathrm{N}$ uptake for whole plants for chickpea and durum wheat. Values represent the average of 10 replicates \pm SE (standard errors). $p$-values from ANOVA (Cropping system, season, and cropping system $\times$ season).

\begin{tabular}{|c|c|c|c|c|c|c|c|}
\hline \multirow[b]{2}{*}{ Season } & \multirow[b]{2}{*}{ Crop } & \multicolumn{3}{|c|}{ Durum Wheat } & \multicolumn{3}{|c|}{ Chickpea } \\
\hline & & $\begin{array}{l}\text { N Shoot } \\
\left(\mathrm{mg} \mathrm{g}^{-1}\right)\end{array}$ & $\begin{array}{c}\text { N Root } \\
\left(\mathrm{mg} \mathrm{g}^{-1}\right)\end{array}$ & $\begin{array}{c}\text { N Uptake } \\
\text { (kg ha) }\end{array}$ & $\begin{array}{l}\text { N Shoot } \\
\left(\mathrm{mg} \mathrm{g}^{-1}\right)\end{array}$ & $\begin{array}{c}\text { N Root } \\
\left(\mathrm{mg} \mathrm{g}^{-1}\right)\end{array}$ & $\begin{array}{c}\text { N Uptake } \\
\left(\text { mg plant }^{-1}\right)\end{array}$ \\
\hline & & Mean \pm SE & Mean \pm SE & Mean \pm SE & Mean \pm SE & Mean \pm SE & Mean \pm SE \\
\hline \multirow[t]{2}{*}{2015} & Intercrop & $5.9 \pm 0.3^{a}$ & $1.3 \pm 0.1^{b}$ & $110.4 \pm 8.1^{\mathrm{a}}$ & $15 \pm 0.3^{a}$ & $4.3 \pm 0.4^{\mathrm{a}}$ & $60.6 \pm 0.3^{b}$ \\
\hline & Sole crop & $3.7 \pm 0.2^{b}$ & $1.7 \pm 0.06^{\mathrm{a}}$ & $50.1 \pm 0.6^{c}$ & $9.5 \pm 0.3^{b}$ & $2.9 \pm 0.1^{b}$ & $37.8 \pm 0.3^{c}$ \\
\hline \multirow[t]{3}{*}{2016} & Intercrop & $3.7 \pm 0.2^{b}$ & $0.8 \pm 0.07^{c}$ & $137.6 \pm 5.6^{b}$ & $7.1 \pm 0.2^{b c}$ & $1.6 \pm 0.2^{b c}$ & $87.6 \pm 6.1^{a}$ \\
\hline & Sole crop & $2.8 \pm 0.1^{\mathrm{c}}$ & $0.6 \pm 0.06^{c}$ & $63 \pm 2.4^{c}$ & $5.9 \pm 0.2^{\mathrm{d}}$ & $1.8 \pm 0.2^{c}$ & $89.1 \pm 7.7^{\mathrm{a}}$ \\
\hline & & $p$ value & $p$ value & $p$ value & $p$ value & $p$ value & $p$ value \\
\hline \multicolumn{2}{|c|}{ Crop } & $\leq 0.001$ & 0.18 & $\leq 0.001$ & $\leq 0.001$ & 0.002 & $\leq 0.04$ \\
\hline \multicolumn{2}{|c|}{ Season } & $\leq 0.001$ & $\leq 0.001$ & 0.17 & $\leq 0.001$ & $\leq 0.001$ & $\leq 0.001$ \\
\hline \multicolumn{2}{|c|}{ Crop $\times$ Season } & $\leq 0.001$ & $\leq 0.001$ & 0.08 & 0.11 & $\leq 0.001$ & 0.02 \\
\hline
\end{tabular}

Different letters indicate significant difference between means and they were determined by Tukey test.

Table 2. Phosphorus concentration in shoots and roots and P uptake for whole plants for chickpea and durum wheat. Values represent the average of 10 replicates $\pm S E$ (standard errors). $p$-values from ANOVA (Cropping system, season, and cropping system $\times$ season).

\begin{tabular}{|c|c|c|c|c|c|c|c|}
\hline \multirow[b]{2}{*}{ Season } & \multirow[b]{2}{*}{ Crop } & \multicolumn{3}{|c|}{ Durum Wheat } & \multicolumn{3}{|c|}{ Chickpea } \\
\hline & & $\begin{array}{l}\text { P Shoot } \\
\left(\mathrm{mg} \mathrm{g}^{-1}\right)\end{array}$ & $\begin{array}{c}\text { P Root } \\
\left(\mathrm{mg} \mathrm{g}^{-1}\right)\end{array}$ & $\begin{array}{l}\text { P Uptake } \\
\text { (kg ha) }\end{array}$ & $\begin{array}{l}\text { P Shoot } \\
\left(\mathrm{mg} \mathrm{g}^{-1}\right)\end{array}$ & $\begin{array}{c}\text { P Root } \\
\left(\mathrm{mg} \mathrm{g}^{-1}\right)\end{array}$ & $\begin{array}{c}\text { P Uptake } \\
\left(\mathrm{mg} \text { plant }^{-1}\right)\end{array}$ \\
\hline & & Mean \pm SE & Mean \pm SE & Mean \pm SE & Mean \pm SE & Mean \pm SE & Mean \pm SE \\
\hline \multirow[t]{2}{*}{2015} & Intercrop & $1.2 \pm 0.008^{c}$ & $1.2 \pm 0.007^{\mathrm{b}}$ & $26.8 \pm 2.8^{b}$ & $1.1 \pm 0.05^{\mathrm{c}}$ & $1 \pm 0.003^{c}$ & $5.8 \pm 0.5^{c}$ \\
\hline & Sole crop & $1.4 \pm 0.02^{b}$ & $1.3 \pm 0.03^{a}$ & $21 \pm 1.9^{c}$ & $1.1 \pm 0.05^{c}$ & $1.1 \pm 0.005^{b}$ & $4.7 \pm 0.4^{c}$ \\
\hline \multirow[t]{3}{*}{2016} & Intercrop & $1.1 \pm 0.01^{c}$ & $1.1 \pm 0.01^{\mathrm{b}}$ & $42.8 \pm 0.2^{\mathrm{a}}$ & $1.2 \pm 0.07^{b}$ & $1.1 \pm 0.01^{b}$ & $6.6 \pm 0.9^{b}$ \\
\hline & Sole crop & $1.9 \pm 0.06^{\mathrm{a}}$ & $1.5 \pm 0.09^{a}$ & $44.1 \pm 1.2^{a}$ & $1.5 \pm 0.03^{a}$ & $1.3 \pm 0.03^{a}$ & $9.5 \pm 0.5^{\mathrm{a}}$ \\
\hline & & $p$ value & $p$ value & $p$ value & $p$ value & $p$ value & $p$ value \\
\hline \multicolumn{2}{|c|}{ Crop } & $\leq 0.001$ & $\leq 0.001$ & 0.025 & $\leq 0.001$ & 0.02 & $\leq 0.001$ \\
\hline \multicolumn{2}{|c|}{ Season } & $\leq 0.001$ & 0.33 & $\leq 0.01$ & 0.5 & 0.08 & $\leq 0.001$ \\
\hline \multicolumn{2}{|c|}{ Crop $\times$ Season } & $\leq 0.001$ & 0.01 & 0.35 & 0.09 & 0.2 & 0.024 \\
\hline
\end{tabular}

Different letters indicate significant difference between means and they were determined by Tukey test.

$\mathrm{P}$ concentration and $\mathrm{P}$ uptake by both chickpea and durum wheat were significantly affected by both cropping system and the interaction between cropping system and year, except for both total $P$ uptake by durum wheat and P shoot concentration in chickpea (Table 2). For 2015, the total P uptake was significantly higher by $28 \%$ for durum wheat and by $25 \%$ for chickpea as a sole crop in 2016 season, which had the highest value of measured P uptake. Furthermore, the P concentration in the shoots was significantly higher for sole crops than for intercrops for durum wheat (16\% in 2015 and $72 \%$ in 2016) and chickpea in 2016 (20\%, but not for chickpea in 2015 (Table 2). Similar results were found for the $\mathrm{P}$ concentration in the roots, being significantly higher for sole crops than for intercrops for durum wheat (8.3\% in 2015 and 36\% in 2016) and chickpea (10\% in 2015 and 18\% in 2016).

On an average, the $\mathrm{N}$ uptake for intercropped durum wheat being more than double that of sole-cropped durum wheat in both growing seasons (2015 and 2016). However, the P uptake for the intercrops was significantly higher than for the sole crops only during the first growing season.

\subsection{Nitrogen Index Nutrition (NNI) and LER for N and P Uptake}

The nitrogen nutrition index (NNI) for durum wheat and chickpea grown as intercrops and sole crops is shown in Figure 5A,B. For both growing seasons, NNI was below 1 for both durum wheat and chickpea grown as intercrops and as sole crops, indicating low $\mathrm{N}$ availability in the experimental conditions. The NNI was higher for intercropping (in 2015, the NNI was 0.09 for chickpea and 0.050 
for durum wheat, and in 2016, it was 0.11 for chickpea and 0.052 for durum wheat) than for sole crops (in 2015, the NNI was 0.038 for chickpea and 0.035 for durum wheat, and in 2016, it was 0.099 for chickpea and 0.03 for durum wheat). The values of $0.09,0.050,0.11$, and 0.052 indicate that $\mathrm{N}$ availability for the crops was only $9 \%, 5 \%, 11 \%$, and $5.2 \%$ of the critical level. For chickpea, in 2015, the NNI was significantly higher (136\%) when grown as an intercrop rather than a sole crop, but in 2016, there was no significant difference (Figure 5A). For durum wheat, the NNI was significantly higher (48\% in 2015 and 77\% in 2016) when grown as a sole crop (Figure 5B). LER was significantly higher than 1 only for $\mathrm{N}$ uptake (1.71 in 2015 and 1.58 in 2016), whereas it was less than 1 for P uptake (0.91 in 2015 and 0.82 in 2016, Figure 4C).
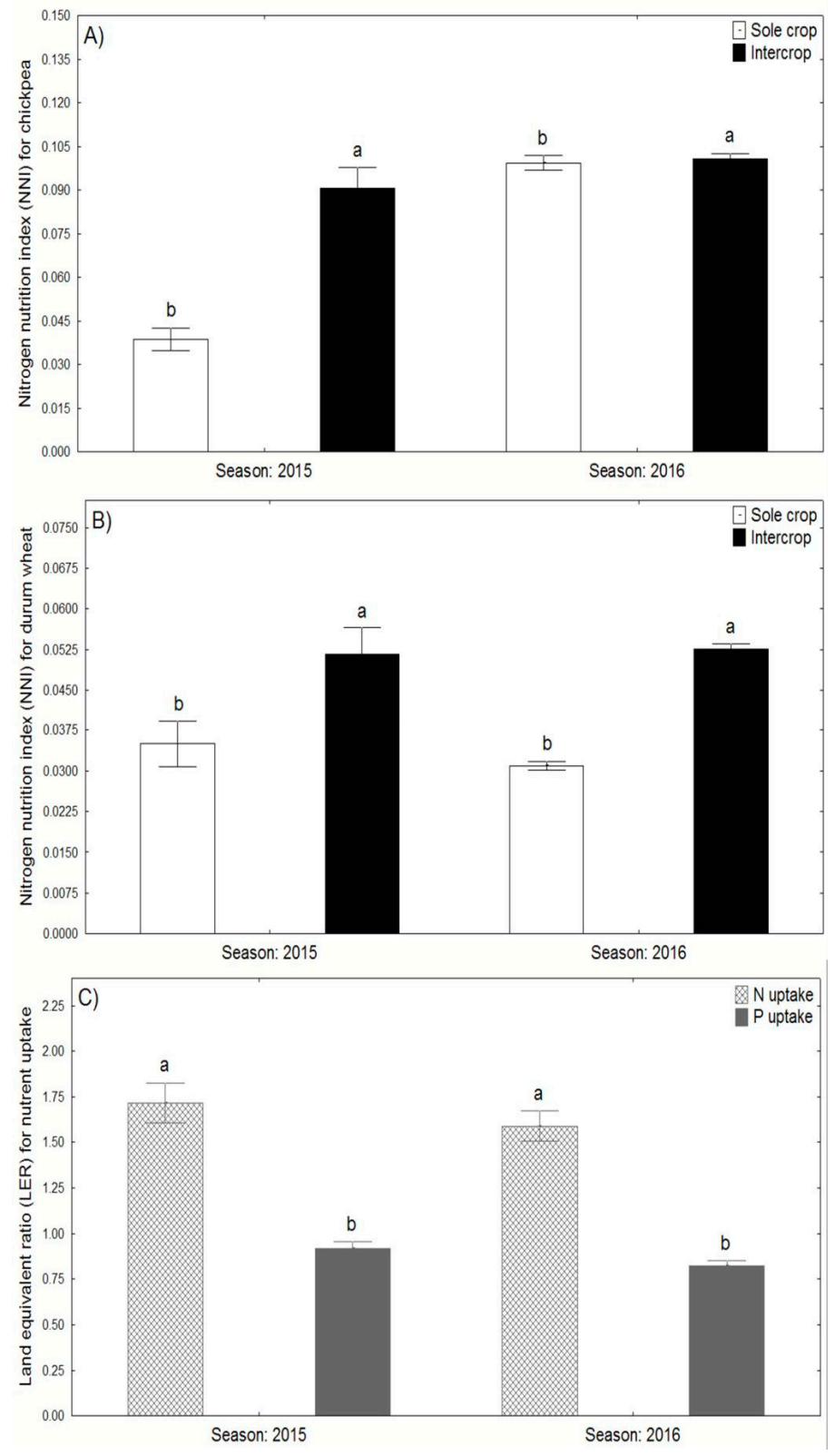

Figure 5. Nitrogen nutrition index (NNI) for chickpea (A) and durum wheat (B) as sole crops and intercrops, and LER (C) for N and P uptake in 2015 and 2016. Values represent the average of 10 replicates $\pm \mathrm{SE}$ (standard errors). $p$-values from ANOVA (cropping system, season, and cropping system $\times$ season). Bars with the different letters compare cropping systems and years within a crop and are significantly different at $p<0.05$. 


\subsection{Rhizosphere P and N Availability}

The average inorganic $\mathrm{N}\left(\mathrm{N}-\mathrm{NO}_{3}{ }^{-}+\mathrm{N}-\mathrm{NH}_{4}{ }^{+}\right)$and Olsen $\mathrm{P}$ concentrations in the rhizosphere for intercrops and sole crops are given in Figure $6 \mathrm{~A} / \mathrm{C}$ and Figure $6 \mathrm{~B} / \mathrm{D}$, respectively. The inorganic $\mathrm{N}$ concentration in the chickpea rhizosphere for both intercrops and sole crops was higher than in the fallows (Figure 6A). The rhizosphere $\mathrm{N}$ concentration was significantly higher for sole crops than for the fallows (62\% in 2015 and 37\% in 2016) and slightly less for intercropping (48\% in 2015 and $13 \%$ in 2016) (Figure 6A). However, the inorganic N concentration was significantly higher in the rhizosphere of intercropped durum wheat than in that of durum wheat as a sole crop (49\% in 2015 and $19 \%$ in 2016, Figure 6C). The N concentration in the soil in the fallows was significantly higher (32\%) than in the rhizosphere of durum wheat when grown as a sole crop in 2015 (Figure 6C). The Olsen P concentration in the rhizosphere was always significantly higher in the cultivated plots than in the fallows. For both chickpea and durum wheat, the P Olsen in the rhizosphere was not significantly higher in the intercrops than in the sole crops in 2015. However, in 2016, the Olsen P in the rhizosphere of both intercrops and sole crops was significantly higher than in the fallows (Figure 6B,D), but the difference was greater for intercropping ( $80 \%$ for chickpea and $75 \%$ for durum wheat) than for sole cropping (35\% for chickpea and $52 \%$ for durum wheat).
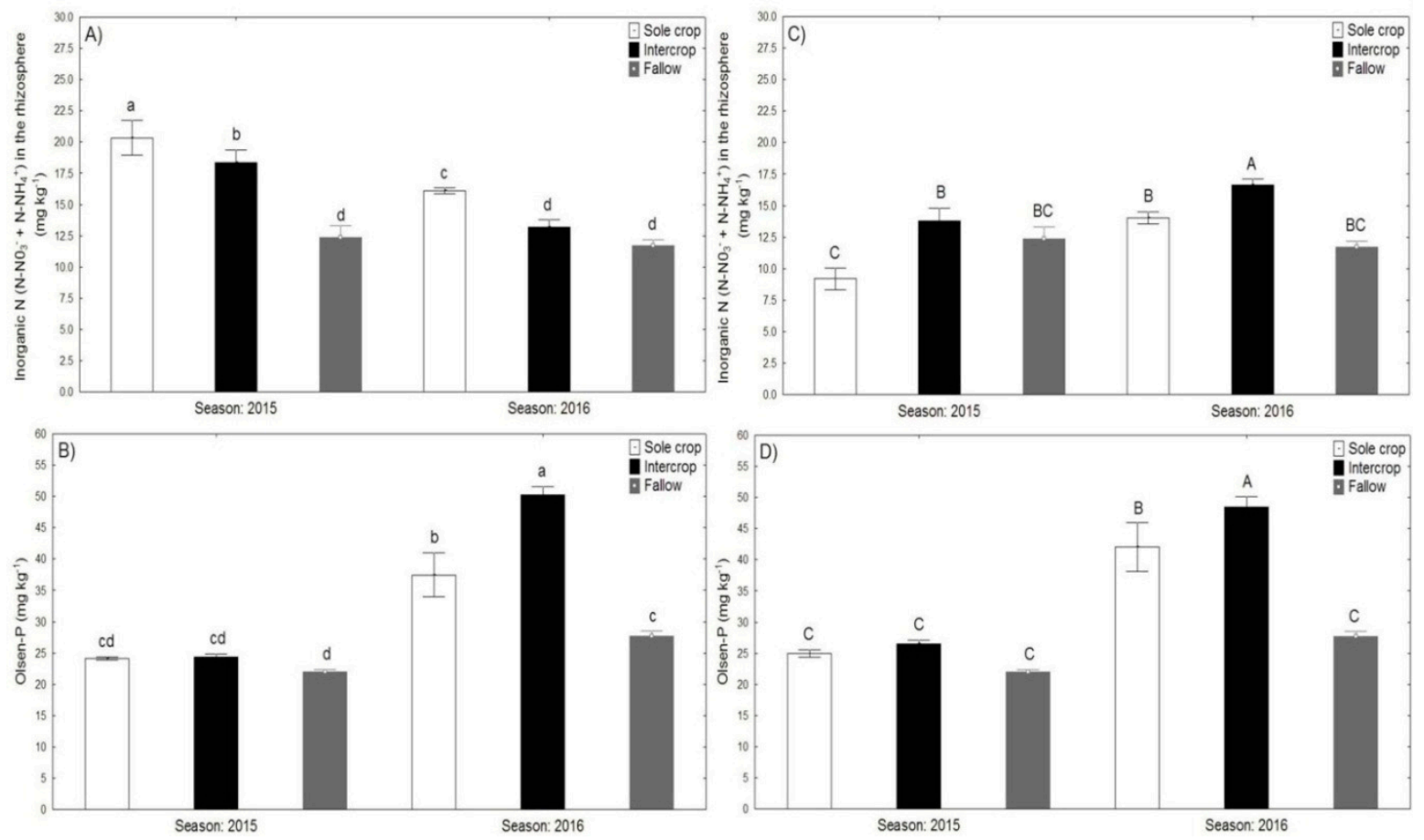

Figure 6. Inorganic $\mathrm{N}\left(\mathrm{N}_{-} \mathrm{NO}_{3}{ }^{-}+\mathrm{N}-\mathrm{NH}_{4}{ }^{+}\right)$and Olsen $\mathrm{P}$ in the rhizosphere of chickpea $(\mathbf{A}, \mathbf{B})$ and durum wheat $(\mathbf{C}, \mathbf{D})$ as sole crops and intercrops and for the fallows. Data are means and SE of 12 rhizosphere samples taken 120 days after sowing. Bars with the different letters compare cropping systems and years within a crop and are significantly different at $p<0.05$.

\section{Discussion}

The results of this research study confirmed that, for an N-deficient, alkaline soil, there was a significant increase in both shoot and root biomass for durum wheat intercropped with chickpea in comparison with sole-cropped durum wheat. This change in shoot and root biomass was observed during the first (2014-2015) and the second season (2015-2016), except for shoot dry weight during the first season (Figure 1A). However, shoot and root biomasses were significantly lower for chickpea when it was intercropped with durum wheat (Figure 1A,B). Under the same conditions of sampling period (full flowering stage), previous studies have shown that the growth of cereal is facilitated by a 
legume and that durum wheat and maize biomass is likely to increase when intercropped with faba bean and cowpea, respectively [12,27]. Indeed, the total shoot dry weight (SDW) and grain yield of mixed durum wheat and chickpea were significantly higher in intercrops in the first and following years than in the sole cropping of both chickpea and durum wheat (Figures 2A and 3A). Wang et al. [28] reported a significant increase in above-ground biomass of intercropped faba bean during continuous maize-faba bean intercropping for 10 years.

Legumes, which can adapt to different cropping patterns and can fix atmospheric nitrogen, may help sustain increased plant biomass and grain yield for the species with which they are intercropped [29]. This increased biomass results mainly from interspecific facilitation of nutrient use between the durum wheat and chickpea that was observed during first growing season. Recent studies confirmed the benefit of intercropping for cereal through facilitation mechanisms made by intercropped legume, which was responsible for increasing inorganic $\mathrm{P}$ and $\mathrm{N}$ availability by rhizosphere acidification during $\mathrm{N}_{2}$ fixation $[9,30]$. The increase in LER $\mathrm{biomass}_{\text {TDW }}$ of mixture crop was less pronounced during the second growing season; it is possible that this reduction was directly related to the increase in dry weight of sole-cropped chickpea during the second season (Figure 1A). Such increase is presumably due to a higher EURS (Figure 4C) and P availability (Figure 6B) in the rhizosphere of chickpea when it was grown as a sole crop in the second year (Figure 3B) as compared with first year. This could be attributed to the better improving of agricultural sustainability by optimizing the trade-off between productivity (e.g., plant biomass) and efficiency in use of environmental resources in a cereal/legume intercropping system $[17,28]$.

In an N-deficient soil observed in this study, the above-ground yield of mixture crop was significantly higher for intercrops than in sole crops in both years (Figure 3A). The higher LER for intercropping (TDW of both species) showed a plant biomass advantage over a sole cropping system in both years (Figure 3B). Intercropping provided yield advantages for chickpea/durum wheat, which may be due to the improvement of efficiency in use of resources via both functional complementarity and facilitation between intercropped chickpea and durum [3]. In a P-deficient, alkaline soil, a previous study showed that, for maize/cowpea and maize/common bean intercropping, the maize grain yield was $25 \%$ greater than for the corresponding sole cropping $[7,10]$. Chickpea and durum wheat were sown at the same time and matured at about the same time (chickpea maturity: 15-20 days later than durum wheat), thus maximizing the durum wheat competition and nutrients use facilitation by intercropped chickpea (e.g., $\mathrm{N}$ and P). Our results are also in good agreement with the literature on intercropping such as barley-pea [22] in terms of growth and grain yield improvement under the $\mathrm{N}$-deficient soil condition.

In low $\mathrm{N}$ soil conditions, there was significantly lower nodule biomass for intercropped chickpea than for chickpea grown as sole crop in either first or second year (Figure 2B). Betencourt et al. [9] and Latati et al. [12] reported a similar effect of intercropping on $\mathrm{N}_{2}$ fixation and nodule growth. These results, however, disagree with Maingi et al. [31] and Banik et al. [32], who found that nodule biomass was higher for intercropping due to a beneficial association of cereal and legume. In this study, the decrease in nodule biomass of intercropped chickpea (Figure 6B) would probably have resulted from strong interspecific competitions with intercropped durum wheat roots for rhizosphere $P$ resource. Thus, low nodules biomass could be also due to a change in the population of efficient rhizobial strains (e.g., increasing number of small-sized nodules) involved in efficient nodulation, with higher nitrogenase activity [16,19]. However, low $\mathrm{N}$ availability at the experimental site resulted in significantly higher efficiency of rhizobial symbiosis for chickpea in both intercrops and the second year of sole cropping (Figure 4B,C) compared with the first year of sole cropping (2015). The chickpea EURS was much greater for intercrops than for sole crops in 2015, a difference of $7 \mathrm{~g}$ DW shoot ${ }^{-1} \mathrm{DW}$ nodule (Figure 4A,B). However, in 2016, the sole crop had an EURS which was only slightly greater than that of the intercrop, a difference of only $3 \mathrm{~g}$ DW shoot $\mathrm{g}^{-1} \mathrm{DW}$ nodule, with low correlation between SDW and NDW (Figure 4C,D). The high EURS for chickpea found for intercrops may provide an important clue to the key processes influencing EURS in an N-deficient, alkaline soil. This increase of 
chickpea EURS would probably have resulted from strong interspecific interactions with intercropped durum wheat roots, which promoted the stimulation of legume biological $\mathrm{N}_{2}$ fixation, especially in N-poor soil condition. [10,12] showed a similar EURS change for cowpea and common bean when intercropped with maize, but this change remains poorly understood in a P-deficient alkaline soil. The beneficial effect of chickpea for intercropped durum wheat may have resulted from higher $\mathrm{N}$ nutrition due to either symbiotic use of $\mathrm{N}$ through $\mathrm{N}_{2}$ fixation or a decrease in interspecific competition [9]. However, there was competition from durum wheat: the $\mathrm{N}$ uptake by chickpea being much greater in sole crop than in intercrops (more than 25\% in 2015 and 100\% in 2016). In this study (P sufficiency), the $\mathrm{P}$ concentration in shoots and P uptake by intercropped plants was significantly lower, even though the soil had high $P$ availability.

There was a significant increase in NNI for durum wheat grown in both years of intercropping (Figure 5B), which was still much less than 1 for both chickpea and durum wheat (Figure 5A,B). However, there was no significant difference in NNI between the second year for both intercropped and sole-cropped chickpea. There is complementary $\mathrm{N}$ use between cereals and $\mathrm{N}_{2}$-fixing legumes, where both species are competing for the same pool of soil $\mathrm{N}$, while only the legume can access the pool of atmospheric $\mathrm{N}_{2}$ through symbiotic $\mathrm{N}_{2}$ fixation [33]. Facilitation occurs when one species improves the growth and $\mathrm{N}$ uptake of another species [34]. In this study, the advantage of intercropping durum wheat and chickpea was confirmed for $\mathrm{N}$ acquisition by both chickpea and durum wheat. This intercropping advantage resulted in a 50\% higher $\mathrm{N}$ uptake than for sole crop in either year (Figure 5C). However, sole cropping was more efficient for P uptake (10\% higher) than intercropping (Figure 5C).

Analyzing the $\mathrm{N}$ and $\mathrm{P}$ uptake by intercropped chickpea and durum wheat also added value in explaining the increase in intercropping above-ground biomass. This is clearly seen under $\mathrm{N}$-deficient soil, where intercropped durum wheat (compared with sole-cropped wheat) increased both above-ground biomass and $\mathrm{N}$ uptake by durum wheat. Enhancing the $\mathrm{N}$ uptake appears to be in agreement with previous studies reported by Naudin et al. [6] and Wang et al. [28]. However, in the P-sufficient soil, intercropping decreased P uptake by both intercropped chickpea and durum wheat. Similarly, a study by Latati et al. [10] showed that the P acquisition by intercropped cereals with legumes under P-sufficient conditions substantially decreased compared with sole-cropped cereals.

In $\mathrm{N}$-deficient, alkaline soil, the increases in rhizosphere $\mathrm{P}$ and $\mathrm{N}$ availability were probably related to the high chickpea EURS when it was grown in intercrop with durum wheat. EURS is one of the most important biological indicators for monitoring environmental changes in the rhizosphere of intercropped legumes. Legumes relying on $\mathrm{N}_{2}$ fixation generally help to increase $\mathrm{P}$ and $\mathrm{N}$ availability in the rhizosphere of intercropped cereal through rhizosphere acidification mechanisms [9-11].

In this study, there was greater $\mathrm{P}$ availability (Olsen $\mathrm{P}$ ) in the rhizosphere for both intercropping and sole cropping in both years compared with the fallows. This was significantly greater in the rhizosphere of intercropped durum wheat than for the sole cropping (Figure 6B,D). These results are for a soil which was not P-deficient, but previous results also showed a significant increase in $\mathrm{P}$ availability in the rhizosphere of intercropped cereals in low-P soils $[9,14]$. We suggest that $\mathrm{P}$ availability in the rhizosphere may be affected not only by $\mathrm{P}$ deficiency but also by low $\mathrm{N}$ availability, which can promote $\mathrm{P}$ availability through the root-induced processes in an alkaline soil, for example, rhizosphere acidification by legumes (exudation of phosphatases, carboxylates and/or indirectly through microbial activities) $[12,13,29]$. Based on the stress-gradient hypothesis, recent research reported the advantage of intercropping for cereal through facilitation mechanisms made by legume, which was responsible for increasing inorganic resources availability (e.g., inorganic $\mathrm{P}$ ) by rhizosphere acidification during $\mathrm{N}_{2}$ fixation. Such positive interactions are particularly valuable when soil conditions are limited, such as in alkaline or calcareous P-deficient soils $[12,35,36]$.

Our findings show that wheat-chickpea intercropping increased $\mathrm{N}$ availability in the rhizosphere soil, it also enhanced the above-ground biomass and $\mathrm{N}$ uptake by intercropped species, suggesting a functional complementarity between legumes and cereals grown in intercropping through symbiotic 
nitrogen fixation. This symbiosis is especially important as it concurs with all developmental strategies and leads to sustainable environment in Algerian agroecosystems.

\section{Conclusions}

This study determined the effect of intercropping chickpea and durum wheat on above-ground biomass, yield, and $\mathrm{N}$ and $\mathrm{P}$ acquisition in alkaline and $\mathrm{N}$-deficient soils as a result of symbiotic $\mathrm{N}_{2}$ fixation. The increased above-ground biomass and grain yield were associated with the stimulation of efficiency in use of the rhizobial symbiosis (indicating higher symbiosis efficiency), soil $\mathrm{P}$ and $\mathrm{N}$ availability, and soil resource use efficiency. In the $\mathrm{N}$-deficient soil, intercropping affected positively $\mathrm{N}$ uptake, in particular for the durum wheat, whose above-ground improvement was likely driven by the below-ground legume performances. Although there was lower $P$ uptake by chickpea and durum wheat in the intercrops, the interactions between the species significantly improved $\mathrm{N}$ nutrition for durum wheat in this N-deficient, alkaline soil. The study showed that intercrops (chickpea-durum wheat) are advantageous as they increase above-ground biomass, $\mathrm{N}$ uptake, and grain yield. The results confirmed the importance of interspecific facilitation, improving $\mathrm{N}$ availability in the rhizosphere through the increase of EURS for intercropped legume grown in N-deficient soil. Additional experimental researches on farmers' field conditions are required to confirm and further explore the ecological intensification of chickpea and durum wheat cultivated either in intercropping or in rotation. However, in the context of the large-scale agricultural production of these crops, and from a practical point of view, the mechanization of intercropping harvesting could play an important role in the intensification of the intercropping chickpea-durum wheat which is currently practiced by farmers, especially in family farms.

Supplementary Materials: The following are available online at http://www.mdpi.com/2073-4395/9/11/765/s1, Figure S1: Ombrothermic diagram recorded from December 2014 to June 2015 and from November 2015 to May 2016 at the El Harrach weather station, $10 \mathrm{~km}$ from Algiers, Algeria. Bar graph represents rainfall $(\mathrm{mm})$ and line graph shows average monthly temperatures $\left({ }^{\circ} \mathrm{C}\right) . \mathrm{S}, \mathrm{F}$ and $\mathrm{H}$ indicating sowing, full flowering stage and harvest of durum wheat and chickpea, respectively. Figure S2: Crop plots of field experiment illustrate the growth development of sole cropped chickpea (A) and intercropped durum wheat at flowering (B), full flowering (C) and harvest stage (D).

Author Contributions: M.L.: Research questions determination and hypothesis formulation with the manuscript writing, field management and revision. Corresponding author. P.D. and A.A.: English editing and sentences reformulation. N.Y.R.: Phosphorus measurement and parameters calculation. R.T., E.H. and F.Z.H.: Crop field management and sampling of plant and soil, biomass and grain yield measurement. F.B. and S.M.O.: General lecture and checking of manuscript sentences.

Funding: This work has been prepared with the support of "RUDN university program 5-100.

Acknowledgments: The authors would like to thank the "Centre Nationale de Contrôle et de Certification des Semences" (CNCC-Algiers) and the "Institut technique des grandes cultures" (ITGC-Setif) for providing the durum wheat and chickpea cultivars. We thank also Mr. Sid Ali Hanin (field technician-ENSA) and Mr. Derradji Farid (laboratory engineer-ENSA) for their contribution in this research work.

Conflicts of Interest: The authors declare no conflict of interest.

\section{References}

1. Lemaire, G.; Meynard, J.M. Use of the nitrogen nutrition index for analysis of agronomical data. In Diagnosis on the Nitrogen Status in Crops; Lemaire, G., Ed.; Springer: Heidelberg, Germany, 1997; pp. 45-55.

2. Dawson, C.J.; Hilton, J. Fertiliser availability in a resource-limited world: Production and recycling of nitrogen and phosphorus. Food Policy 2011, 36, 14-22. [CrossRef]

3. Latati, M.; Benlahrech, S.; Lazali, M.; Tellah, S.; Kaci, G.; Takouachet, R.; Alkama, N.; Hamdani, F.Z.; Hafnaoui, E.A.; Belarbi, B.; et al. Intercropping promotes the ability of legume and ccereal to facilitate phosphorus and nitrogen acquisition through root- induced processes. In Grain Legumes; Goyal, A.K., Ed.; E-Publishing Intech: Rijeka, Croitia, 2016; pp. 127-139. [CrossRef] 
4. Lambers, H.; Shane, M.W.; Cramer, M.D.; Pearse, S.; Veneklaas, E. Root structure and functioning for efficient acquisition of phosphorus: Matching morphological and physiological traits. Ann. Bot. 2006, 98, 693-713. [CrossRef] [PubMed]

5. Latati, M.; Pansu, M.; Drevon, J.J.; Ounane, S.M. Advantage of Intercropping Maize (Zea mays L.) and Common Bean (Phaseolus vulgaris L.) on Yield and Nitrogen Uptake in Northeast Algeria. IJRAS 2013, 1, 1-7.

6. Naudin, C.; Corre-Hellou, G.; Pineau, S.; Crozat, Y.; Jeuffroy, M.H. The effect of various dynamics of $\mathrm{N}$ availability on winter pea-wheat intercrops: Crop growth, $\mathrm{N}$ partitioning and symbiotic $\mathrm{N}_{2}$ fixation. Field Crop Res. 2010, 119, 2-11. [CrossRef]

7. Bedoussac, L.; Journet, E.-P.; Hauggaard-Nielsen, H.; Naudin, C.; Corre-Hellou, G.; Jensen, E.S.; Justes, E. Ecological principles underlying the increase of productivity achieved by cereal-grain legumes in organic farming. Agron. Sustain. Dev. 2015, 35, 911-935. [CrossRef]

8. Hinsinger, P.; Betencourt, E.; Bernard, L.; Brauman, A.; Plassard, C.; Shen, J.; Tang, X.; Zhang, F. P for two sharing a scarce resource soil phosphorus acquisition in the rhizosphere of intercropped species. Plant Physiol. 2011, 156, 1078-1086. [CrossRef]

9. Betencourt, E.; Duputel, M.; Colomb, B.; Desclaux, D.; Hinsinger, P. Intercropping promotes the ability of durum wheat and chickpea to increase rhizosphere phosphorus availability in a low P soil. Soil Biol. Biochem. 2012, 46, 21-33. [CrossRef]

10. Latati, M.; Bargaz, A.; Belarbi, B.; Lazali, M.; Benlahrech, S.; Tellah, S.; Kaci, G.; Drevon, J.J.; Ounane, S.M. The intercropping common bean with maize improves the rhizobial efficiency, resource use and grain yield under low phosphorus availability. Eur. J. Agron. 2016, 72, 80-90. [CrossRef]

11. Brooker, R.W.; Bennett, A.E.; Cong, W.F.; Daniell, T.J.; George, T.S.; Hallett, P.D.; Hawes, C.; Iannetta, P.P.M.; Jones, H.J.; Karley, A.J.; et al. Improving intercropping: A synthesis of research in agronomy, plantphysiology and ecology. New Phytol. 2014, 206, 107-117. [CrossRef]

12. Latati, M.; Blavet, D.; Alkama, N.; Laoufi, H.; Drevon, J.J.; Gérard, F.; Pansu, M.; Ounane, S.M. The intercropping cowpea-maize improves soil phosphorus availability and maize yields in an alkaline soil. Plant Soil 2014, 85, 181-191. [CrossRef]

13. Li, H.; Shen, J.; Zhang, F.; Clairotte, M.; Drevon, J.J.; Le Cadre, E.; Hinsinger, P. Dynamics of phosphorus fractions in the rhizosphere of common bean (Phaseolus vulgaris L.) and durum wheat (Triticumturgidum durum L.) grown in monocropping and intercropping systems. Plant Soil 2008, 312, 139-150. [CrossRef]

14. Devau, N.; Le Cadre, E.; Hinsinger, P.; Gérard, F. Effects of inorganic fertilization and pH on processes and mechanisms controlling dissolved inorganic phosphorus in soils. Geochim. Cosmochim. Acta 2011, 75, 2980-2996. [CrossRef]

15. Alkama, N.; Bolou Bi Bolou, E.; Vailhe, H.; Roger, L.; Ounane, S.M.; Drevon, J.J. Genotypic variability in P use efficiency for symbiotic nitrogen fixation is associated with variation of proton efflux in cowpea rhizosphere. Soil Biol. Biochem. 2009, 41, 1814-1823. [CrossRef]

16. Alkama, N.; Ounane, G.; Drevon, J.J. Is genotypic variation of $\mathrm{H}^{+}$efflux under P deficiency linked with nodulated-root respiration of $\mathrm{N}_{2}$-fixing common-bean (Phaseolus vulgaris L.)? J. Plant Physiol. 2012, 169, 1084-1089. [CrossRef] [PubMed]

17. Latati, M.; Aouiche, A.; Tellah, S.; Laribi, A.; Benlahrech, S.; Kaci, G.; Ouarem, F.; Ounane, S.M. Intercropping maize and common bean enhances microbial carbon and nitrogen availability in low phosphorus soil under Mediterranean conditions. Eur. J. Soil Biol. 2017, 80, 9-18. [CrossRef]

18. Lynch, J.M.; Barbano, D.M. Kjeldahl nitrogen analysis as a reference method for protein determination in dairy products. J. AOAC Int. 1999, 82, 1389-1398.

19. Houassine, D.; Latati, M.; Rebouh, Y.N.; Gerard, F. Phosphorus acquisition processes in the field: Study of faba bean cultivated on calcareous soils in Algeria. Arch. Agron. Soil Sci. 2019. [CrossRef]

20. Shen, A.L.; Li, X.Y.; Kanamori, T.; Arao, T. Effect of long-term application of compost on some chemical properties of wheat rhizosphere and non-rhizosphere soils. Pedosphere 1996, 6, 355-363.

21. Leo, M.W.M. Determination of soil carbonates by a rapidegasometric method. J. Agric. Food Chem. 1963, 11, 452-455. [CrossRef]

22. Hauggaard-Nielsen, H.; Ambus, P.; Jensen, E.S. Temporal and spatial distribution of roots and competition for nitrogen in pea-barley intercrops: A field study employing $32 \mathrm{P}$ technique. Plant Soil 2001, 236, 63-74. [CrossRef] 
23. Lemaire, G.; Jeuffroy, M.; Gastal, F. Diagnosis tool for plant and crop N status in vegetative stage Theory and practices for crop N management. Eur. J. Agric. 2008, 28, 614-628. [CrossRef]

24. Plènet, D.; Lemaire, G. Relationships between dynamics of nitrogen uptake and dry matter accumulation in maize crops. Determination of critical N concentration. Plant Soil 2000, 216, 65-82. [CrossRef]

25. Bargaz, A.; Ghoulam, C.; Amenc, L.; Lazali, M.; Faghire, M.; Abadie, J.; Drevon, J.J. A phosphoenol pyruvate phosphatase transcript is induced in the rootnodule cortex of Phaseolus vulgaris under conditions of phosphorus deficiency. J. Exp. Bot. 2012, 63, 4723-4730. [CrossRef]

26. Drevon, J.J.; Alkama, N.; Araujo, A.; Beebe, S.; Blair, M.W.; Hamza, H.; Jaillard, B.; Lopez, A.; Martinez-Romero, E.; Rodino, P.; et al. Nodular diagnosis for ecological engineering of the symbiotic nitrogen fixation with legumes. Proc. Environ. Sci. 2011, 9, 40-46. [CrossRef]

27. Ibrahim, H.; Hatira, A.; Pansu, M. Modelling the functional role of microorganisms in the daily exchanges of carbon between atmosphere, plants and soil. Proc. Environ. Sci. 2013, 19, 96-105. [CrossRef]

28. Wang, Z.; Bao, X.; Li, X.; Jin, X.; Zhao, J.; Sun, J.; Christie, P. Intercropping maintains soil fertility in terms of chemical properties and enzyme activities on a timescale of one decade. Plant Soil 2014. [CrossRef]

29. Jeyabal, A.; Kuppuswamy, G. Recycling of organic wastes for the production of vermicompost and its response in rice-legume cropping system and soil fertility. Eur. J. Agric. 2001, 15, 153-170. [CrossRef]

30. Li, Y.Y.; Yu, C.; Cheng, X.; Li, C.J.; Sun, J.H.; Zhang, F.S.; Lambers, H.; Li, L. Intercropping alleviates the inhibitory effect of $\mathrm{N}$ fertilization on nodulation and symbiotic $\mathrm{N}_{2}$ fixation of faba bean. Plant Soil 2009, 323, 295-308. [CrossRef]

31. Maingi, M.J.; Shisanya, A.C.; Gitonga, M.N.; Hornetz, B. Nitrogen fixation by common bean (Phaseolus vulgaris L.) in pure and mixed stands in semi-arid south east Kenya. Eur. J. Agron. 2011, 14, 1-12. [CrossRef]

32. Banik, P.; Midya, A.; Sarkar, B.K.; Ghose, S.S. Wheat and chickpea intercropping systems in an additive series experiment: Advantages and weed smothering. Eur. J. Agric. 2006, 24, 325-332. [CrossRef]

33. Callaway, R.M. Positive interactions among plants. Bot. Rev. 1995, 61, 306-349. [CrossRef]

34. Song, Y.N.; Zhang, F.S.; Marschner, P.; Fan, F.L.; Gao, H.M.; Bao, X.G.; Sun, J.H.; Li, L. Effect of intercropping on crop yield and chemical and microbiological properties in rhizosphere of wheat (Triticumaestivum L.), maize (Zeamays L.), and faba bean (Viciafaba L.). Biol. Fertil. Soil 2007, 43, 565-574. [CrossRef]

35. Devau, N.; Hinsinger, P.; Le Cadre, E.; Gérard, F. Root-induced processes controlling phosphate availability in soils with contrasted P-fertilized treatments. Plant Soil 2011, 348, 203-218. [CrossRef]

36. Pelzer, E.; Bazot, M.; Makowski, D.; Corre-Hellou, G.; Naudin, C.; Baranger, E.; Bedoussac, L.; Biarnès, V.; Boucheny, P.; Carrouée, B.; et al. Pea-wheat intercrops in low-input conditions combine high economic performances and low environmental impacts. Eur. J. Agron. 2012, 40,39-53. [CrossRef] 